\title{
Homogenisation of a gridded snow water equivalent climatology for Alpine terrain: methodology and applications
}

\author{
S. Jörg-Hess ${ }^{1}$, F. Fundel ${ }^{1, *}$, T. Jonas ${ }^{2}$, and M. Zappa ${ }^{1}$ \\ ${ }^{1}$ Swiss Federal Institute for Forest, Snow and Landscape Research (WSL), Zürcherstr. 111, 8903 Birmensdorf, Switzerland \\ ${ }^{2}$ WSL Institute for Snow and Avalanche Research SLF, Flüelastr. 11, 7260 Davos, Switzerland \\ *now at: Deutscher Wetterdienst (DWD), Frankfurter Straße 135, 63067 Offenbach, Germany
}

Correspondence to: S. Jörg-Hess (stefanie.joerg@wsl.ch)

Received: 13 June 2013 - Published in The Cryosphere Discuss.: 26 August 2013

Revised: 6 February 2014 - Accepted: 6 February 2014 - Published: 19 March 2014

\begin{abstract}
Gridded snow water equivalent (SWE) data sets are valuable for estimating the snow water resources and verify different model systems, e.g. hydrological, land surface or atmospheric models. However, changing data availability represents a considerable challenge when trying to derive consistent time series for SWE products. In an attempt to improve the product consistency, we first evaluated the differences between two climatologies of SWE grids that were calculated on the basis of data from 110 and 203 stations, respectively. The "shorter" climatology (2001-2009) was produced using 203 stations (map203) and the "longer" one (1971-2009) 110 stations (map110). Relative to map203, map110 underestimated SWE, especially at higher elevations and at the end of the winter season. We tested the potential of quantile mapping to compensate for mapping errors in map110 relative to map203. During a $9 \mathrm{yr}$ calibration period from 2001 to 2009, for which both map203 and map110 were available, the method could successfully refine the spatial and temporal SWE representation in map 110 by making seasonal, regional and altitude-related distinctions. Expanding the calibration to the full $39 \mathrm{yr}$ showed that the general underestimation of map 110 with respect to map203 could be removed for the whole winter. The calibrated SWE maps fitted the reference (map203) well when averaged over regions and time periods, where the mean error is approximately zero. However, deviations between the calibrated maps and map203 were observed at single grid cells and years. When we looked at three different regions in more detail, we found that the calibration had the largest effect in the region with the highest proportion of catchment areas above $2000 \mathrm{~m}$ a.s.1. and that the general underestimation of map 110 compared to
\end{abstract}

map203 could be removed for the entire snow season. The added value of the calibrated SWE climatology is illustrated with practical examples: the verification of a hydrological model, the estimation of snow resource anomalies and the predictability of runoff through SWE.

\section{Introduction}

Snow plays a crucial role in the hydrological cycle of mountainous catchments (Thayyen and Gergan, 2010; Barnett et al., 2005; Schär et al., 2004). During winter and at high elevations, snow is a temporary buffer for precipitation (Foppa and Seiz, 2012; Foppa et al., 2005; Viviroli et al., 2003). It reduces runoff during winter, but contributes to the total runoff during spring snowmelt. In Switzerland, for example, snow is especially relevant as $30 \%$ of the country's annual precipitation falls as snow (Sevruk, 1986), and snowmelt contributes to about $40 \%$ of the total annual runoff (Bernhard and Zappa, 2012). This is why finding a good way to represent the state of snow storage is so relevant for hydrological modelling.

Anomalies in the available snow water resources can impact the hydrological properties of a catchment even several months after the snowfall. Significant changes in runoff during spring and summer may be due to anomalies in the winter snow cover (Cayan et al., 1993). Including an accurate specification of the snowpack for the months preceding model initialisation in seasonal forecasts of hydrological models has been shown to improve the forecast (Day, 1985; Laternser and Schneebeli, 2003; Clark and Hay, 2004; 
Schär et al., 2004; Hock et al., 2006; Bierkens and van Beek, 2009; Pagano et al., 2009; Koster et al., 2010).

Long series of high-quality snow storage data (snow climatologies) are desirable for many applications. Some examples include the risk assessment of droughts and floods, for example, to estimate the return periods of critical events (Beniston, 2012); the classification of winters according to their snow availability; the parameter calibration, validation and development of hydrological models (Garen and Marks, 2005; Liston and Elder, 2006; Parajka and Blöschl, 2008; Warscher et al., 2013); the validation of snow cover simulations from regional climate models (Steger et al., 2012) and land-surface models (Dutra et al., 2011); and the study of changes in the water balance of large-scale basins such as the Rhine river, where snow significantly contributes to the total runoff (Mauser et al., 2007; Poulin et al., 2011).

Snow information is usually obtained for hydrological models via remotely sensed snow cover products or in situ observations (Andreadis and Lettenmaier, 2005; Clark et al., 2006; Slater and Clark, 2006). To provide accurate snow storage information for catchments and larger regions, spatially distributed snow water equivalent (SWE) information is desirable.

Estimating the spatial snow depth distribution in Switzerland has been the focus of several studies. Witmer et al. (1986) considered the regional and topographical dependencies in seven climatological regions in Switzerland to calculate gridded maps of climatological monthly snow depths (mean, median and 80th percentile) based on data from 160 snow stations. They found that the linear dependency of snow depth and elevation cannot account for the local variability in the snow depth. In a different approach Auer et al. (2004) describe the correlation between snow depth and altitude using an area-wide base value. This value is adjusted with a compensation value based on the regional residuals between the base value and the measured values. At the Swiss Federal Institute for Snow and Avalanche Research, Davos (SLF), such a snow depth map is produced on a weekly basis during the winter months. Generating gridded snow maps typically involves tackling various obstacles. The correct placing of the seasonal snow line is challenging if the estimation is based on station measurements. Another difficulty is that snow observations at lower altitudes are often not conducted in early winter and spring. Snow information from real-time snow cover maps based on satellite data can significantly improve the gridded snow information, and have thus been integrated into SLF's operational production of snow depth maps (Foppa et al., 2005, 2007).

In Switzerland daily snow depth readings are recorded at hundreds of stations, but SWE measurements are rarely made and only about 40 locations provide biweekly data. However, with snow density models (e.g. Jonas et al., 2009; Sturm et al., 2010) it is possible to convert operational snow depth maps into SWE maps.
A similar concept is used in this study to produce base climatologies in the form of daily SWE maps (see Sect. 3.1). However, varying station densities over the past decades mean that the mapping accuracies also vary greatly over time. To investigate and mitigate this problem, two climatologies with daily SWE maps were analysed: a long-term data set (39 yr, 1971-2009) based on a small number (110) of stations, i.e. a sparse network, and a short-term data set $(9 \mathrm{yr}$, 2001-2009) based on considerably more stations (203), i.e. a dense network. Data from sites above $2000 \mathrm{~m}$ a.s.l. are only contained in the second data set. As about $23 \%$ of Switzerland is above $2000 \mathrm{~m}$ a.s.l., accurate information about the snow mass at higher altitudes is crucial. These two data sets are used to demonstrate the homogenisation procedure.

The aim of this study was to identify a calibration methodology that can refine the gridded SWE maps based on the sparse station network, so that they can be homogenised with the maps based on the dense station network. The statistical calibration method "quantile mapping" is applied, where a quantile according to the non-exceedance probability in the "sparse" climatology is modified to meet the quantile of the same non-exceedance probability in the "dense" climatology (Panofsky and Brier, 1968). The improvement of the calibrated maps is evaluated and their added value for selected practical applications is tested. Possible applications of the data set are demonstrated with three examples: (1) SWE climatologies are compared with SWE estimated with a hydrological model, (2) snow resource anomalies are estimated based on the SWE climatologies, and (3) predicting low flow at the main river gauge of the Alpine Rhine catchment in Neuhausen is evaluated.

\section{Study regions and data}

\subsection{Test catchments}

Gridded SWE maps were created, calibrated and evaluated for the whole of Switzerland. A detailed evaluation is presented here for three sub-areas, namely the Alpine Rhine, Valais and the region including the rivers Thur, Töss and Glatt (Fig. 1). The regions were selected to take into account different elevation ranges and assess the importance of snow as a controlling element of the runoff regime. The main characteristics of the three regions are given in Table 1. The Alpine Rhine and the Valais are Alpine catchments where the seasonal shape of runoff generation is strongly influenced by snow and glacier melting with a distinct summer maximum. The annual mean runoff is $1200 \mathrm{~mm}$ in the Alpine Rhine and $1100 \mathrm{~mm}$ in the Valais. The highest runoff is observed during spring in the region of the rivers Thur, Töss and Glatt, with an annual mean runoff of $850 \mathrm{~mm}$. Catchment average yearly precipitation sum and mean temperature are calculated from the meteorological forcing used by Zappa et al. (2012) for a hydrological simulation for all of Switzerland 
Table 1. Characteristics of the three regions Alpine Rhine (AR), Valais (VS) and Thur/Töss/Glatt (TTG) and the distribution of SWE stations within these catchments.

\begin{tabular}{lrrr}
\hline & AR & TTG & VS \\
\hline Size [km²] & 6342 & 2586 & 5382 \\
Mean elevation [m a.s.1] & 1742 & 696 & 2078 \\
Min elevation [m a.s.1] & 409 & 345 & 372 \\
Max elevation [m a.s.1] & 3361 & 2324 & 4403 \\
\% above 2000 & 39.25 & 0.04 & 56.02 \\
Number of SWE stations & 43 & 8 & 43 \\
Mean elevation of SWE stations & 1706 & 925 & 1996 \\
Max elevation of SWE stations & 2725 & 1610 & 2950 \\
\hline
\end{tabular}

during the period 1980-2009. Precipitation is high in the region of the rivers Thur, Töss and Glatt $\left(1400 \mathrm{~mm} \mathrm{yr}^{-1}\right)$ and in the Alpine Rhine $\left(1300 \mathrm{~mm} \mathrm{yr}^{-1}\right)$, and slightly lower in the Valais $\left(1000 \mathrm{~mm} \mathrm{yr}^{-1}\right)$. The annual average temperature is affected by the altitudes of the catchment. It is rather low in the Valais $\left(1.8^{\circ} \mathrm{C}\right)$ and in the Alpine Rhine $\left(3.1^{\circ} \mathrm{C}\right)$, and higher in the region of the rivers Thur, Töss and Glatt $\left(8.1^{\circ} \mathrm{C}\right)$.

\subsection{Snow observations}

A common measure in monitoring snow resources is the height of the snow cover (HS). To estimate the available water resources in specific areas, however, the SWE is a more relevant variable as it represents the water content of snow. In Switzerland, more HS measurements are available than SWE measurements simply due to the fact that measuring HS requires less effort than measuring SWE. However, HS and SWE are strongly correlated with each other (Sturm et al., 2010).

The gridded SWE maps used in this study were derived from HS measurements from several station networks. Automated measurements are available from the ANETZ ( $\mathrm{Au}$ tomatisches MessNETZ) and ENET (ErgänzungsNETZ) networks of the Federal Office of Meteorology and Climatology MeteoSwiss and from IMIS (Interkantonales Mess- und Informationsystem), run by SLF. Moreover, the SLF observers for the avalanche forecast service record manual HS readings daily.

Over the past decades the number and extent of measurement sites in Switzerland has increased steadily. The IMIS network was founded in the late 1990s and extended the existing networks to elevations above $2000 \mathrm{~m}$ a.s.l. For the creation of the gridded SWE maps, stations were selected according to data availability and representativeness. Two sets of HS measurements, based on a different number of stations and spanning different periods were built for the calibration (Fig. 1): 110 stations from 1971 to 2009 (d110, purple dots) and 203 stations from 2001 to 2009 (d203; purple, orange and green dots). A third data set, based on 23 stations from
1989 to 2009 (d23, orange dots), was used to validate the calibration procedure before 2001. The measurement accuracy depends on the equipment and accounts for about $\pm 2 \mathrm{~cm}$.

The stations available in d203 in the Alpine Rhine (43 stations) and the Valais (43 stations) are well distributed. In the region of the rivers Thur, Töss and Glatt the eight available stations (d203) are located close to its border. The mean elevation of the station sets is equal to the mean elevation of the respective regions (Table 1). However the stations are not well representative for the highest part of the target areas.

Based on daily HS measurements (d110 and d203), gridded SWE climatology maps (map110 and map203) were produced for Switzerland with the model described in Sect. 3.1. All data sets and gridded maps used in this study are summarised in Table 2.

\subsection{Runoff observations}

For the application example in Sect. 5.1, daily runoff records from the river gauge in Neuhausen (yellow triangle in Fig. 1), operated by the Swiss Federal Office for the Environment, were used. The river gauge Neuhausen is located downstream of Lake Constance $\left(>500 \mathrm{~km}^{2}\right)$, at an altitude of $383 \mathrm{~m}$ a.s.l., with a drainage area of $11887 \mathrm{~km}^{2}$. The catchment of the Alpine Rhine is affected by lake regulation, river corrections and hydropower.

\section{Methods}

\subsection{Snow water equivalent mapping}

Maps of SWE are produced using a two-step procedure. The available HS station data are first converted to SWE, and then mapped onto grid using a snow-specific detrended distance weighting approach. To calculate SWE from the observed HS, an estimation of the snow bulk density $\rho b$ is required:

$\mathrm{SWE}=\rho b \cdot \mathrm{HS}$.

Snow bulk density can be predicted from the HS, day of the year, altitude and snow region in Switzerland using a parametric model (Jonas et al., 2009). The model was calibrated on a data set of 11000 SWE-HS measurements from 48 winters (1960-2008) and 37 stations throughout the Swiss Alps, and is thus particularly suitable for this study. For this data set the root-mean-squared error of the estimated SWE compared to SWE measurements is about $50 \mathrm{~mm}$ (Jonas et al., 2009). We used an enhanced version of the model to mitigate a problem noticeable when the model is applied to convert a time series of daily data, as noted in Jonas et al. (2009). Contrary to the original version of the model, the enhanced version is now capable of distinguishing snowpack settling from snowmelt by assimilating daily HS data instead of a singular HS reading only. The approach is similar to concepts presented in Martinec and Rango (1991). 


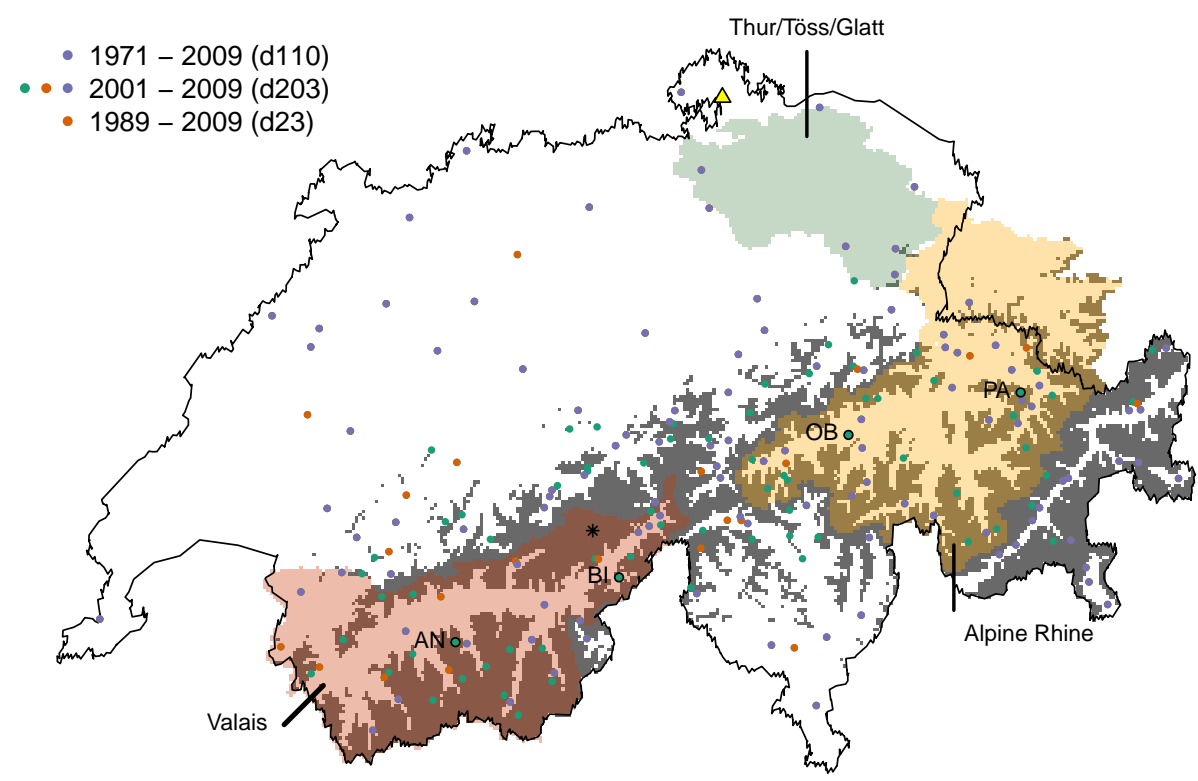

Fig. 1. Stations available during the different time periods: 110 stations from 1971 to 2009 (d110, purple dots), 203 stations from 2001 to 2009 (d203, purple, orange and green dots) and 23 stations from 1989 to 2009 (d23, orange dots). The three sub-areas - Alpine Rhine, Valais and the region including the rivers Thur, Töss and Glatt - are considered in this study. Areas shaded grey are higher than $2000 \mathrm{~m}$ a.s. 1 . The four labelled stations with black outlines are used for validation. The yellow triangle is the river gauge in Neuhausen. The black star is a grid cell chosen for illustration in Sect. 4.3 .

Daily SWE data estimated for each of the stations used for the climatologies were mapped onto a digital elevation model with a horizontal resolution of $1 \mathrm{~km}$. A non-linear trend of SWE over elevation was first calculated for each day using median values calculated for overlapping elevation windows. Detrended SWE values, i.e. the offset of each reading from the trend, are then interpolated to the grid using a distanceweighting approach based on a Gaussian filter for each grid cell $i$. As the SWE distribution is strongly correlated with elevation, we used a linear combination of two separate Gaussian filters, one for horizontal distances (distance $\mathrm{h}_{\mathrm{h}}$ ) and one for vertical distances $\left(\right.$ distance $_{\mathrm{v}}$ ).

Weight $_{i}=\exp \left(-0.5 \cdot\left(\frac{\text { distance }_{\mathrm{h}}}{\text { filterwidth }_{\mathrm{h}}}+\frac{\text { distance }_{\mathrm{v}}}{\text { filterwidth }_{\mathrm{v}}}\right)^{2}\right)$

Optimised filter widths for snow mapping in Switzerland were identified by a leave-one-out cross-validation and are roughly around $25 \mathrm{~km}$ horizontally and $500 \mathrm{~m}$ vertically, depending on the station density and season. Finally, the detrended and mapped SWE data were reprojected onto the digital elevation model.

Gridded SWE time series, that have been produced with the procedure described above were compared to several data sets. Obviously, there exists no experimental data set that would allow for the $1 \mathrm{~km}$ SWE product to be validated at the given spatial and temporal scales. However, as an indirect validation snow-covered area (SCA) derived from our SWE maps were compared to equivalent satellite observations (Hüsler et al., 2014). This comparison covered $20 \mathrm{yr}$ of
Table 2. Grid, number of stations used to produce grid, available data period and role in the study (c: used for calibration; v: used for validation.

\begin{tabular}{|c|c|c|c|}
\hline Grid & Stations & Period & Role in the study \\
\hline map110 & $110(\mathrm{~d} 110)$ & 1971-2009 & $\mathrm{c}$ \\
\hline map203 & $203(\mathrm{~d} 203)$ & 2001-2009 & $\mathrm{c} / \mathrm{v}$ \\
\hline \multirow[t]{2}{*}{ map.cal } & - & 1971-2009 & - \\
\hline & $23(\mathrm{~d} 23)$ & 1989-2009 & $\mathrm{v}$ \\
\hline $\operatorname{map} 203^{-}$ & $203-4$ & 2001-2009 & $\mathrm{c} / \mathrm{v}$ \\
\hline map.cal ${ }^{-}$ & - & 2001-2009 & $\mathrm{v}$ \\
\hline
\end{tabular}

daily SCA data and showed high consistency between both data series in terms of absolute SCA values as well as for temporal dynamics.

The above procedure was applied to calculate the three SWE climatologies outlined in Sect. 2.2. The longest climatology based on 110 stations only allowed for a detrending up to $2100 \mathrm{~m}$ a.s.l. The Thur/Töss/Glatt region is not affected, because only $2 \%$ of the region is above $2100 \mathrm{~m}$ a.s.l. However a large part is above this level in the Alpine Rhine (33\%) and the Valais (52\%). Above this elevation, the SWE maps will probably underestimate the true SWE, as beyond that, the trend continues horizontally by considering the closest stations for estimating the offset from the trend. In contrast, d203 allowed for a detrending up to $2700 \mathrm{~m}$ a.s.l. This additional information for higher elevations reduces the fraction that is considered from the "horizontal" trend in the Alpine 
Rhine $(4 \%)$ and the Valais $(24 \%)$. Consider that grid cells higher than $2700 \mathrm{~m}$ a.s.l. are not validated in this study. Moreover, the increased number of stations enabled a regional detrending using only the nearest 40 stations around each location, resulting in an enhanced resolution of regional patterns.

\subsection{Quantile mapping}

Quantile mapping was used to calibrate map110 based on map203 (Panofsky and Brier, 1968). The method has been applied in other studies for daily precipitation and temperature corrections (Ines and Hansen, 2006; Fundel et al., 2010; Bardossy and Pegram, 2011; Themeß1 et al., 2011; Thrasher et al., 2012), the correction of climate scenarios ( $\mathrm{Li}$ et al., 2010; Veijalainen et al., 2012) and hydrological applications (Wood et al., 2004; Boe et al., 2007). In this study the empirical cumulative distribution function (ECDF) was used. It makes the application very flexible as no assumptions about the distribution are needed (Themeßl et al., 2011).

The exceedance probability of an SWE value in map 110 was assumed to correspond to the quantile of the same exceedance probability in map203. The ECDFs are $F^{1}$ for map110 and $F^{\mathrm{h}}$ for map203 in the overlapping period. The calibrated SWE was then obtained by

$\mathrm{SWE}_{\mathrm{cal}}=F^{\mathrm{h}-1}\left(F^{\mathrm{l}}\left(\mathrm{SWE}_{1}\right)\right)$.

To account for different distributions of SWE in different altitudes, regions and snow amounts we performed quantile mapping separately for subsets of the data predefined in Sect. 4.2. The main advantages of quantile mapping are its simplicity and the applicability to all variables, independent of the underlying distribution. A disadvantage is the handling of "new extremes", which exceed the values within the training period. The maximum for map110 during the period 1971-2000 $(1949 \mathrm{~mm})$ is larger than the maximum during the training period 2001-2009 (1353 mm). Extremes larger than those observed during the training period could be dealt with, for example, performing a double quantile-quantile transformation (Bardossy and Pegram, 2011), extrapolation to values exceeding the observations (Boe et al., 2007), combining extreme value analysis and non-parametric regression methods to fit the tails of the distributions (Bogner et al., 2012) and applying a transfer function based on model output and observations to future or past observations ( $\mathrm{Li}$ et al., 2010). Although there are several ways to deal with such "new extremes", we decided to change the "new extremes" of map110 to the maximum of map110 during the training period. This maximum is exceeded only in $6 \times 10^{-4} \%$ of the sample considered.

Another drawback of quantile mapping is that for individual cases a correction may go in the wrong direction (Hamill and Whitaker, 2006). While bias and variability can be reduced with quantile mapping, errors in the higher-order moments can probably not be removed. Quantile mapping cor-

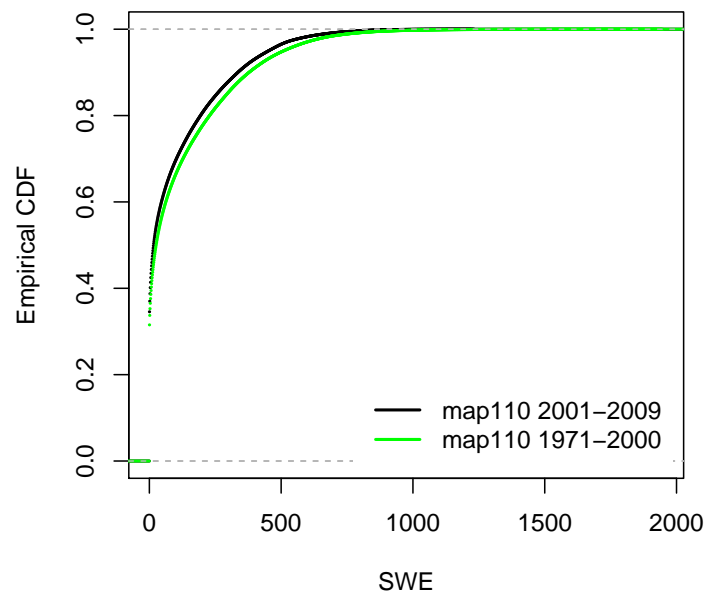

Fig. 2. Comparison of the SWE distribution in map110 during the training period (black) and the calibration period (green).

rects the shape of the distribution function and can therefore also reduce errors in variability (Themeßl et al., 2011).

For the statistical calibration method, quantile mapping, it is important to investigate possible changes in the distribution of SWE during the periods 1971-2000 and 2001-2009. Figure 2 illustrates the CDFs of these two periods. The two distributions can be considered similar, which means it is not necessary to perform a double quantile-quantile transformation or other transfer functions such as those used by, for example, Bardossy and Pegram (2011) and Li et al. (2010).

\subsection{Validation methods}

In this study, map203 is assumed to contain more accurate gridded snow information because it is based on more snow measurements that also cover higher elevations. Therefore map203 is considered as the reference data set.

In a first step SWE estimates are compared to measured snow depth that is converted into SWE over the period 20012009. At each measurement station, SWE was estimated with the associated station $\left(\mathrm{SWE}_{\text {orig }}\right)$ and without $\left(\mathrm{SWE}_{\text {loo-cv }}\right)$. The altitude was adjusted to the station altitude by subtracting the day-specific SWE gradient from the modelled SWE values. "Orig" and "loo-cv" were compared to identify the uncertainty of the model and the impact of individual stations on the mapping results.

Estimated SWE is validated taking into consideration the mean error (ME), the mean absolute error (MAE), the squared correlation coefficient $\left(R^{2}\right)$ and the root-meansquared error (RMSE). In order to ensure that small fluctuations in SWE are preserved, $R^{2}$ is calculated with the seasonal trend removed. Therefore the first-order differences with a lag of $1 \mathrm{yr}$ are used (Wilks, 2006; Foppa et al., 2007; Saloranta, 2012).

After implementing the quantile mapping (Sect. 4.3), which is performed according to the results from comparing 
map203 with map110 (Sect. 4.2), map.cal was validated. First the calibration was tested for the nine overlapping years with a cross-calibration approach. By dividing the data set into a training period ( $8 \mathrm{yr}$ ) and a calibration period (one independent year), each year can be calibrated independently with the remaining $8 \mathrm{yr}$. The relation obtained between the quantiles of the two data sets was then applied to the 39 available years of map 110 .

For the validation of the spatial and temporal consistence "independent" stations are used (Table 2). The temporal validation outside the calibration period is done by comparing the calibrated maps with "independent" measurements from d23 (Fig. 1) during the test period (1989-2000) and the calibration period (2001-2009). Most of these 23 stations are located between 1500 and $2000 \mathrm{~m}$ a.s.l. and three stations are located around $2200 \mathrm{~m}$ a.s.l. For the validation of the spatial consistence a new grid (map203-) based on d203 with four stations removed (stations with the black outline in Fig. 1) is produced. These four stations are then used to validate map203 $3^{-}$and the therewith calibrated grid map.cal ${ }^{-}$.

\section{Results}

\subsection{Quality of the SWE maps at measuring sites}

The spatial variability of the snow cover led to uncertainty in the error statistics, which are based on station data. To put this into perspective, consider the following illustration: if the whole modelling domain was covered by $2 \mathrm{~m}$ of snow, but with a realistic small-scale variability of $\pm 15 \%$ (Jonas et al., 2009), a perfect coarser-scale SWE product would arrive at a homogeneous distribution of $2 \mathrm{~m}$. However, given that station data represent single point measurements with natural deviations from the mean, the resulting RMSE of the real snow depth in the model domain and the modelled snow depth would amount to $33 \mathrm{~cm}$, even though the mapping model is otherwise perfect.

The impact of each individual station on the mapping results and its regional representativeness were investigated with a "leave-one-out cross-validation" approach (LOO$\mathrm{CV})$. The uncertainty of the estimated SWE increases from December to April at many stations (Fig. 3) because the melting process causes large SWE differences between high and low altitudes. Generally $\mathrm{SWE}_{\text {orig }}$ outperforms $\mathrm{SWE}_{\text {loo-cv }}$. It should be considered that a representative value for the region ( $1 \mathrm{~km} \times 1 \mathrm{~km}$ grid) was compared to a single measurement that is unlikely to represent the spatial distribution of snow depth (Blöschl, 1999). However, the small differences between "orig" and "loo-cv" indicate that the uncertainty between the stations is only slightly larger than at the station locations. In Fig. 4 spatial distribution of the RMSE and $R^{2}$ is illustrated. RMSE increases with altitude due to the higher proportion of snow with respect to total precipitation. The small RMSEs at lower elevations, where SWE is generally

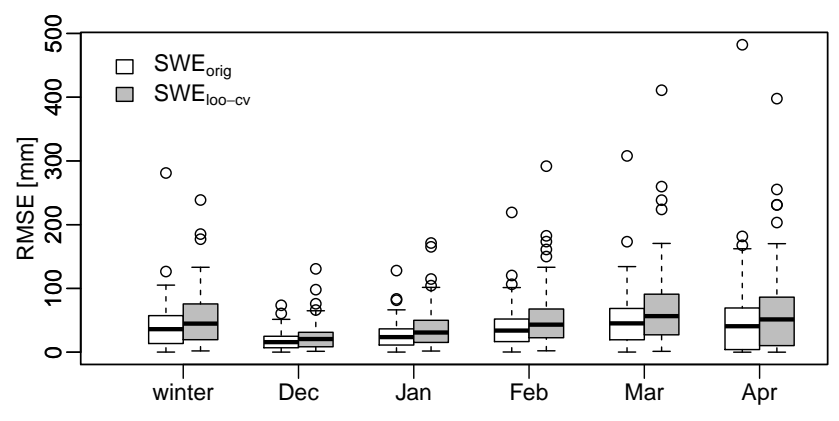

Fig. 3. The effects of season on the root-mean-squared error (RMSE) over the period 2001-2009. White boxes contain the scores for all stations calculated with $\mathrm{SWE}_{\text {orig }}$ and the grey boxes those based on $\mathrm{SWE}_{\text {loo-cv }}$.

small, do not necessarily indicate better performance of the estimations for these regions.

$R^{2}$ is generally very high and seems to be independent of elevation and the related snow amount. In regions with a higher station density, $R^{2}$ is higher. The lowest $R^{2}$ values are observed in regions (and months) where the ablation and accumulation of snow are difficult to separate clearly.

\subsection{Differences between SWE climatologies}

The differences between map110 and map203 ( $\Delta$ SWE ) was analysed for all of Switzerland during the overlapping period to identify systematic errors and to find a meaningful way to subdivide the data in different subsets for the calibration procedure. The RMSE orig for the 110 stations appearing in both data sets is slightly smaller for map203 (34 mm) than for map110 (36 mm). Different aspects such as altitude, snow depth, seasonality and regionally specific characteristics were analysed. Compared to map203, map110 underestimates SWE, especially at high elevations (Fig. 5a). At lower altitudes, however, $\triangle \mathrm{SWE}$ is negligible. This finding comes as no surprise since the 110 available stations for map110 only allowed for a detrending up to $2100 \mathrm{~m}$ a.s.l., but stations from map203 also cover altitudes above $2100 \mathrm{~m}$ a.s.l. It is therefore of no advantage to use, for example, grid cells at an altitude of $2000 \mathrm{~m}$ a.s.l. to calibrate a grid cell at $1000 \mathrm{~m}$ a.s.l. The error characteristics depend on altitude and thus a classification into elevation ranges is justified. The numbers at the bottom of Fig. 5a show the distribution of d203 into the elevation bins used. Most of the stations are located between 1000 and $2500 \mathrm{~m}$ a.s.l. and 18 stations are located at elevations higher than $2500 \mathrm{~m}$ a.s.l. The mean $\triangle \mathrm{SWE}$ is independent of snow depth (Fig. 5b). It is close to zero for both snowrich and snow-poor days, but the variance is higher for snowrich days. The distinction between snow-rich days (SWE exceeds the average) and snow-poor days (SWE smaller than the average) is based on the median in map110. The same days are considered as having correspondingly rich or poor snow resources in map203. The classification into snow-rich 

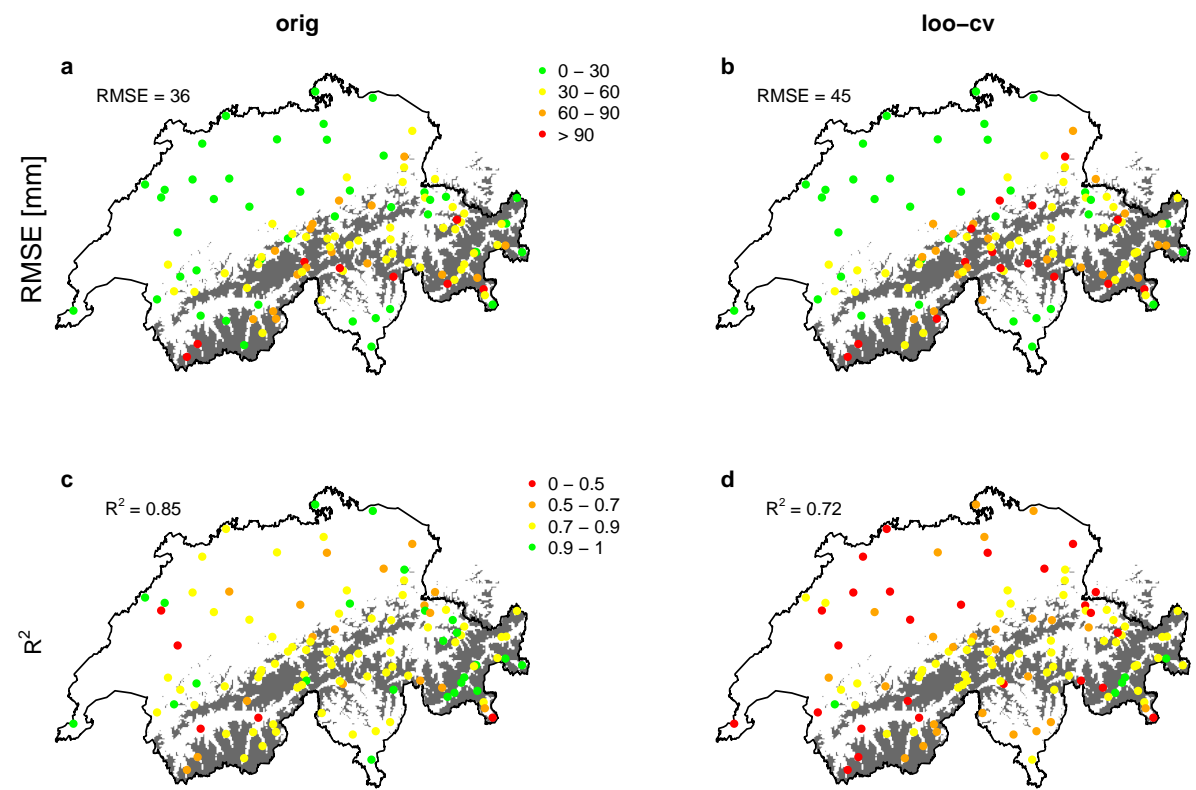

Fig. 4. Statistics for the SWE maps at station grid cells averaged over the period 2001-2009. The scores averaged over all stations are listed in the upper left of each figure. The left column (a and $\mathbf{c})$ contains the scores calculated with $\mathrm{SWE}_{\text {orig }}$ and the right (b and $\left.\mathbf{d}\right)$ those based on $\mathrm{SWE}_{\text {loo-cv }}$. Areas shaded grey are higher than $2000 \mathrm{~m}$ a.s.l.
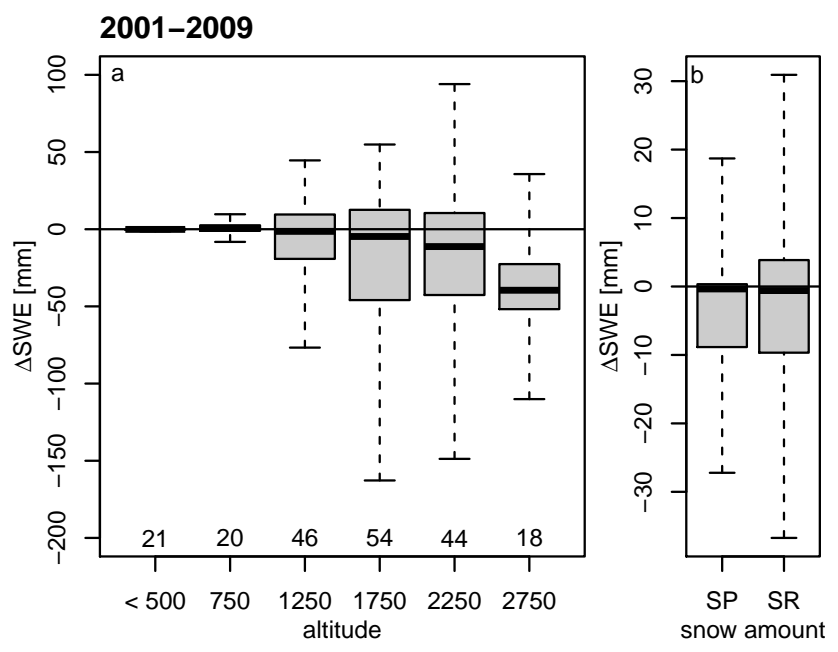

Fig. 5. The mean differences between map110 and map203 per grid cell for (a) different altitude ranges and (b) snow-rich (SR) and snow-poor (SP) days in the whole of Switzerland during the overlapping period. The numbers at the bottom of panel (a) are the numbers of stations per elevation bin. The boxes display the median and the interquartile range. The whiskers extend to the maximum $\triangle \mathrm{SWE}$, but are limited by twice of the interquartile range.

and snow-poor days is justified as the spatial distribution of snow depends on the snow depth (Egli and Jonas, 2009).

$\triangle \mathrm{SWE}$ varies spatially between the regions and altitudes, and temporally between December, January, February, March and April (Fig. 6). From December to April, the $\triangle$ SWE for a large area increases. The SWE trend with eleva-

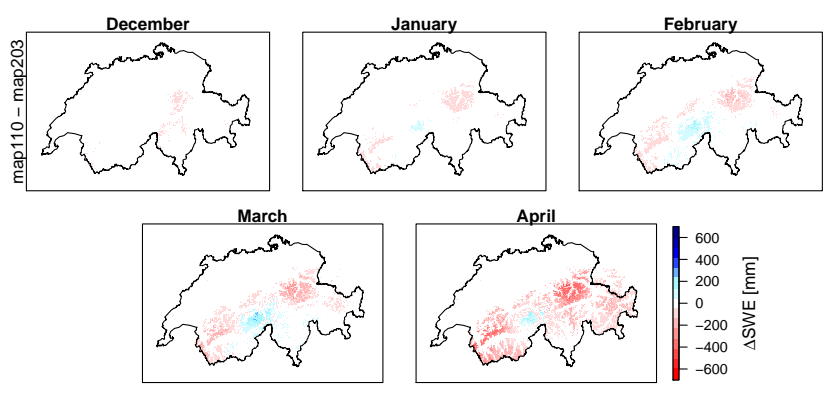

Fig. 6. The mean differences (map110-map203) per grid cell for the five winter months December, January, February, March and April (2001-2009).

tion has a small gradient in December. Therefore, the benefits of having stations at higher elevations are smaller in December than at the end of the winter season. This is confirmed by the fact that $\triangle \mathrm{SWE}$ is small in December and much higher in April. The highest underestimations of map110 are observed in the the Valais and part of the the Alpine Rhine catchment. Overestimations are observed only in the eastern part of the Valais (Gotthard region). The region with the largest $\triangle \mathrm{SWE}$ is similar to the region above $2000 \mathrm{~m}$ a.s.l. (area shaded in grey in Fig. 1). 


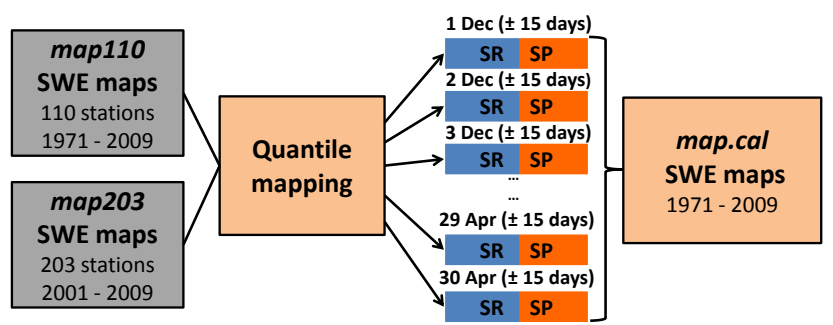

Fig. 7. Calibration procedure. SR refers to snow-rich and SP to snow-poor days. The distinction between snow-rich and snow-poor days is based on the median of map110 during the overlapping period.

\subsection{Implementing the quantile mapping}

The outcome of the comparison of map110 and map203 in the previous section led to the definition of the calibration procedure illustrated in Fig. 7. The calibration of map110 is implemented separately for each grid cell to account for spatial and altitude-dependent differences, and for each day with a moving window of \pm 15 days to account for seasonal effects. Because maps are only available from 1 December until 30 April, reduced classes were used for dates before 15 December and after 15 April. Additionally snow-rich and snow-poor days were distinguished by means of the median SWE in map110. The ECDF of each sub-data set were used for the calibration with quantile mapping. Finally a calibrated data set of gridded SWE maps for $39 \mathrm{yr}$ (map.cal) was produced.

During the nine overlapping years, the calibration of a specific grid cell " $x$ " (star in Fig. 1) on 11 March 2003 uses all days of this grid cell from 24 February to 26 March except those from the year 2003 to produce the ECDFs. Estimated SWE from map203 is used to produce $F_{11}^{\mathrm{h}}$ March x and estimated SWE from map110 is used to produce $F_{11 \text { March x }}^{1}$. The median of $F_{11}^{1}$ March x $493 \mathrm{~mm}$, which we now define as the threshold to discriminate snow-rich from snow-poor days. The same days are also considered as snow-rich and snow-poor in map203. For 11 March 2003 a SWE of $539 \mathrm{~mm}$ is altered to $588 \mathrm{~mm}$ by using only the snow-rich days from map110 and the same days from map203 for the calibration.

For the entire period (39 yr), quantile mapping is, as before, completed for each grid cell and day separately by distinguishing snow-rich and snow-poor days based on the median of map110 during the overlapping period. The reallocation of SWE values follows a simple procedure, which is illustrated here for the grid cell " $x$ " on 16 January 1979. $F_{16 \text { January x }}^{\mathrm{h}}$ and $F_{16}^{1}$ January x contain all January days of grid cell " $x$ " from 2001 to 2009 and 1971 to 2009 , respectively. The threshold to separate snow-rich and snow-poor days is chosen during the overlapping period to ensure that both data sets are separated on the basis of the same conditions. For grid cell " $x$ ", the median SWE on 16 January is $285 \mathrm{~mm}$ from 2001 to 2009 and $297 \mathrm{~mm}$ from 1971 to 2009. For this grid

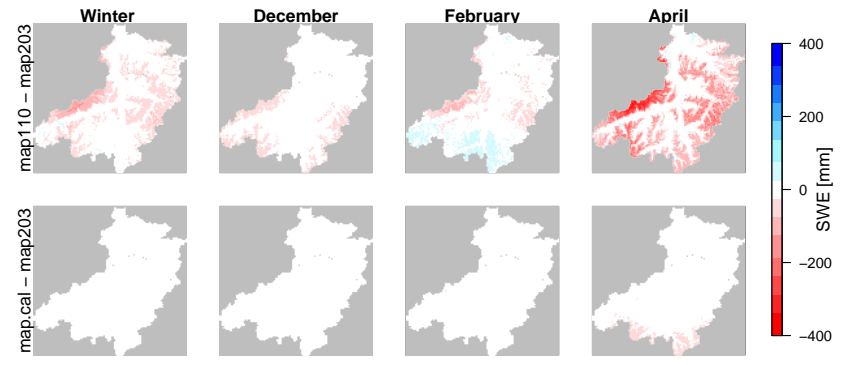

Fig. 8. Mean differences between map110-map203 (top) and map.cal-map203 (bottom) for the whole winter, and for December, February, and April (2001-2009) for the Alpine Rhine.

cell the difference is small. The threshold of $285 \mathrm{~mm}$ classifies the SWE of $299 \mathrm{~mm}$ on 16 January 1979 as snow-rich. Thus $F_{16 \text { January x }}^{\mathrm{l}}$ and $F_{16}^{\mathrm{h}}$ January x use only snow-rich days to calibrate the SWE of 16 January 1979 to a refined value of $302 \mathrm{~mm}$.

\subsection{Validation of the quantile mapping}

The calibrated SWE maps were first validated with map203. As a simple cross-validation for every station is very time consuming, we opted for two different approaches in order to validate our maps during both the calibration period (20012009) and the test period (1989-2000).

\subsubsection{Validation of the calibration period}

In order to validate the calibration period, map203 was considered as reference. The statistical scores are calculated for map110 and map.cal using map203 as a reference. The ME, $R^{2}$ and RMSE were calculated for each grid cell separately and averaged over the Alpine Rhine; the region of the rivers Thur, Töss and Glatt; and the Valais (Table 3). The performance of the SWE simulation differs between map110 and map.cal, as well as between the regions. Map.cal outperforms the uncalibrated map110 in all regions. As expected, after calibration the ME is negligible and RMSE is smaller. $R^{2}$ of the trend-corrected SWE grid cell by grid cell is relatively high, with values above 0.7 . Thus small fluctuations in the snow depth are still reproduced after calibration. At regions above $2000 \mathrm{~m}$ a.s.l., $R^{2}$ is higher after calibration. Otherwise, however, it is generally smaller, because some values in map 110 are shifted to the maximum or minimum in map203, while the SWE in map203 remains variable. As quantile mapping can sometimes correct in the wrong direction, a reduction in the bias is at the expense of the $R^{2}$. Even though the performance is good after calibration, the regional differences persist, especially in $R^{2}$ and RMSE. Some of these differences are related to differences in the altitude ranges and station densities in the three regions investigated.

In the example of the Alpine Rhine region it is shown that systematic over- or underestimations in $\triangle \mathrm{SWE}$, which differ 
Table 3. Mean error (ME), coefficient of determination $\left(R^{2}\right)$ and root-mean-squared error (RMSE) of map110 and map.cal for the three regions: Alpine Rhine (AR), Thur/Töss/Glatt (TTG) and Valais (VS). Stars mark significant differences between map110 and map.cal (at a $95 \%$ confidence level).

\begin{tabular}{lrr|rl|rr}
\hline & \multicolumn{2}{c|}{ AR } & \multicolumn{2}{c|}{ TTG } & \multicolumn{2}{c}{ VS } \\
& map110 & map.cal & map110 & map.cal & map110 & map.cal \\
\hline ME & -18.21 & $0.01^{*}$ & -4.33 & 0.47 & -22.89 & $-0.76^{*}$ \\
$R^{2}$ & 0.86 & $0.81^{*}$ & 0.84 & $0.79^{*}$ & 0.75 & $0.70^{*}$ \\
RMSE & 53.88 & $48.32^{*}$ & 13.91 & $9.26^{*}$ & 78.43 & $60.78^{*}$ \\
\hline
\end{tabular}

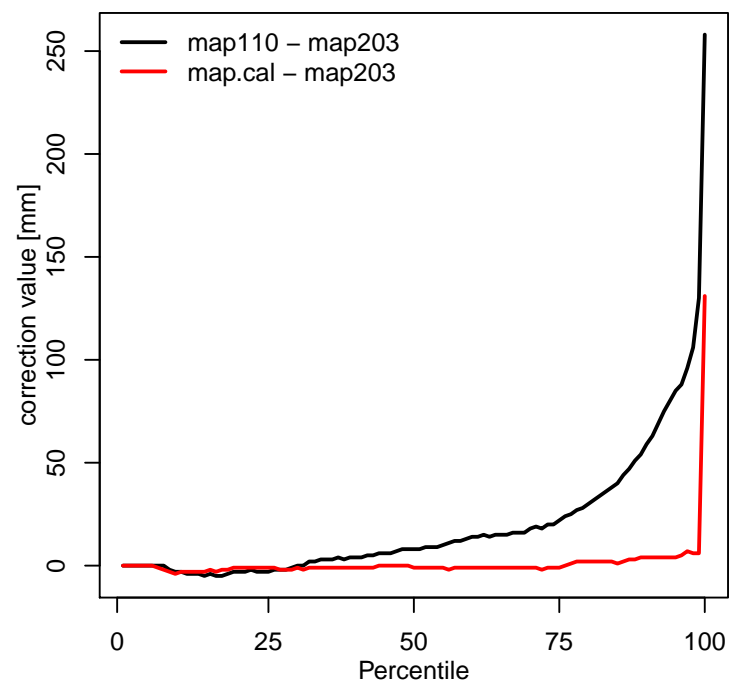

Fig. 9. Differences in percentiles between map203 and map110 (black line) and map203 and map.cal (red line) for the Alpine Rhine during the calibration period.

between months and grid cells (upper row of Fig. 8), could be generally removed through the calibration (lower row of Fig. 8). This is also true for the region of the rivers Thur, Töss, and Glatt as well as the Valais region. The interquartile range of the differences between $\triangle$ SWE and map.calmap203 is unchanged (not shown). Generally, the correction value is more pronounced at high quantiles (Fig. 9). The lowest 30 percentiles of map110 agree well with map203. The calibration is effective for the remaining two-thirds of all values. However the 100th percentile is changed to the maximum of map110 in the calibration period. This is clearly a limitation when adopting quantile mapping.

\subsubsection{Spatial and temporal consistence}

The spatial evaluation is based on map.cal ${ }^{-}$(see Table 2). Generally the interpolation performed without the four selected stations (map203-) results in a higher RMSE (Table 4). In the Valais (Anniviers Orzival and Binn), the RMSE is larger than in the Alpine Rhine (Obersaxen and Parsenn Kreuzweg). The relative effect of removing stations is, how-
Table 4. RMSEs $[\mathrm{mm}]$ at the stations Anniviers Orzival (AN), Binn (BI), Obersaxen (OB) and Parsenn Kreuzweg (PA). Map203 and map.cal are the original versions. Map203 ${ }^{-}$and map.cal ${ }^{-}$are the maps with the four stations removed.

\begin{tabular}{lrrrr}
\hline & map203 & map203- & map.cal & map.cal $^{-}$ \\
\hline AN & 56 & 72 & 101 & 108 \\
BI & 101 & 140 & 96 & 132 \\
OB & 33 & 39 & 37 & 40 \\
PA & 20 & 30 & 63 & 59 \\
\hline
\end{tabular}

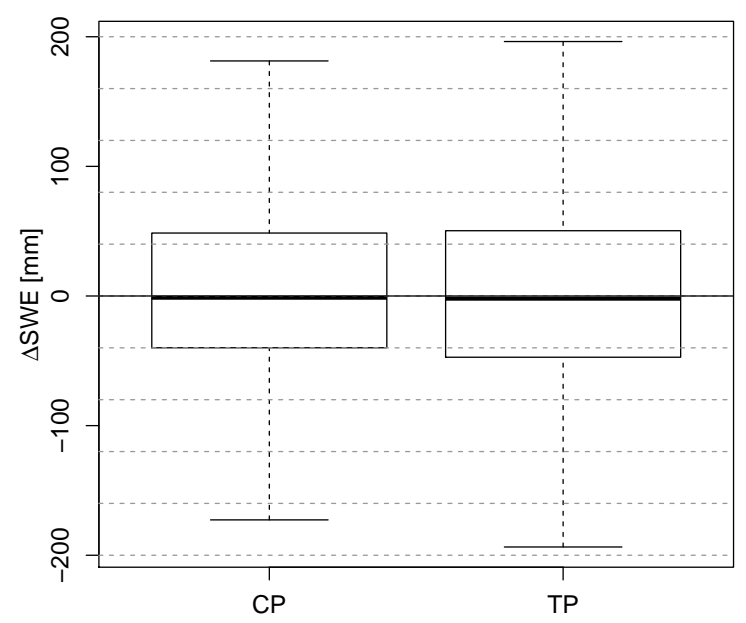

Fig. 10. Mean differences in the calibrated and observed SWE at 23 stations for the calibration period (CP) and the test period (TP). Box and whiskers are shown as in Fig. 5.

ever, greater in the the Alpine Rhine region. For the calibrated maps, the RMSE is only slightly smaller in map.cal than in map.cal ${ }^{-}$, except for Binn. The omission of the selected stations has only a small influence on the uncertainty of the calibrated maps at the station locations. Thus we conclude that the calibration works equally well at grid cells with observations as in between such grid cells.

For the temporal validation the measured and simulated SWE values of 23 "independent" stations are compared during the calibration and the test period. The median of the differences between the calibrated and observed SWE at the 23 stations (Fig. 10) is similar during the calibration period $(-1.3 \mathrm{~mm})$ and the test period $(-2.1 \mathrm{~mm})$, but the interquartile range and total variance are slightly larger during the test period. The mean differences vary between the stations. However, the mean and variance of the differences at most stations are similar between the calibration period and the test period. This similarity indicates that the calibration procedure is temporally consistent. 

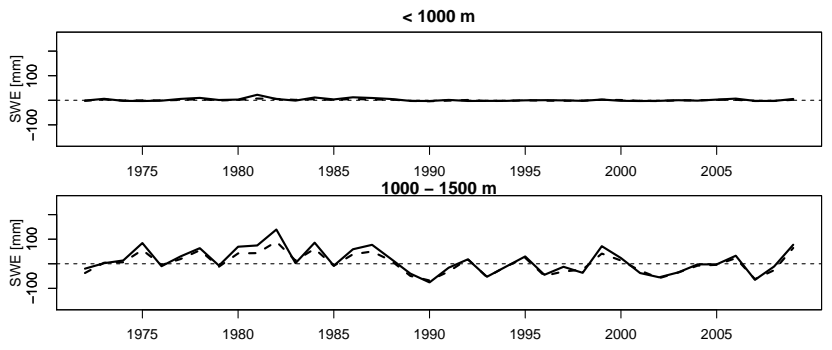

$1500-2000 \mathrm{~m}$

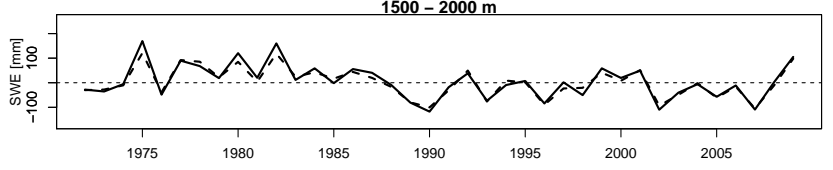

$2000-2500 \mathrm{~m}$

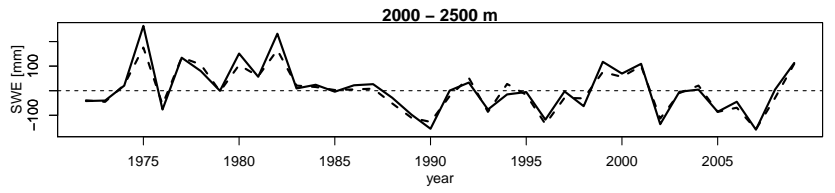

Fig. 11. Anomalies in the median winter SWE [mm] in map110 (black line) and map.cal (dashed line) for different altitude classes.

\subsection{Trend}

SWE anomalies of map110 are maintained in the maps calibrated with map203 (Fig. 11). The linear regression for mean winter SWE resulted in insignificant regression coefficients. However, the coefficients and $p$ values of the linear regression from map110 and map.cal are very similar. Therefore SWE anomalies from the median winter SWE were compared for different altitude ranges. The correlation coefficients of map110 and map.cal are typically very high (>0.85). Based on the station, background anomalies of median winter SWE are expected to be similar up to $2000 \mathrm{~m}$ a.s.l. We expected that there are SWE anomalies that are only present at higher altitudes and thus only covered by map.cal. Such anomalies have, however, not been found in these data sets. The anomalies in SWE are preserved in the $39 \mathrm{yr}$ calibration period. This makes us confident that the method, as we applied it, can be used for different periods in the past and the future.

\section{Three examples of applications}

\subsection{Verification of a hydrological model}

A homogenised and gridded SWE climatology of $39 \mathrm{yr}$ is a valuable data set to verify and calibrate SWE simulated with hydrological models. Hydrological models can be verified against runoff observations. A lot of work is going on in verifying hydrological models against spatial data as remotely sensed data of, for example, snow (Hüsler et al., 2014, 2012; Bellinger et al., 2012; van Dijk and Renzullo, 2011; Zappa, 2008), evapotranspiration (Immerzeel and Droogers, 2008; Kite and Droogers, 2000) and soil mois- ture (Bastiaanssen et al., 1998). SWE simulated with hydrological models is typically calculated with precipitation and temperature (Zappa et al., 2003). In this case the simulated SWE is completely independent of the calibrated SWE maps, as the SWE maps are based on measured HS and calibrated bulk density. An example is given of the fully distributed version of the hydrological model PREVAH (Precipitation Runoff EVApotranspiration Hydrotope) with a spatial resolution of $200 \mathrm{~m}$ (Viviroli et al., 2009a; Kobierska et al., 2013). See Gurtz et al. (1999) and Viviroli et al. (2007) for information on the physics, parameterisation and downscaling method. The regionalised parameters used are from (Viviroli et al., 2009a, b). With the example of a PREVAH simulation from 1 January 1980 to 31 December 2009 (initialisation period from 1 October 1975 to 31 December 1979), SWE was verified for two winters. The meteorological input consists of spatially interpolated meteorological observations calculated according to Viviroli et al. (2009a). Map203 and map 110 provide a database to verify such hydrological models as PREVAH. We have seen that map110 typically underestimates the likely SWE, especially at the end of season, and map203 is not available before 2001. Map.cal provides a consistent SWE data set with more realistic SWE values.

Figure 12 shows the seasonal evolution of the mean SWE in the regions Valais (left), Alpine Rhine (middle) and the Thur/Töss/Glatt catchment for the winters 2007/2008 (top) and 1990/1991 (bottom) for the PREVAH simulation (black). The simulation is available throughout the year but the gridded SWE maps (blue, red and green) are only supplied from 1 December until 31 April. The seasonal evolution of the daily regional SWE is similar between the versions of the same year and region. However the divergence increases towards the end of the winter season. The validation of the PREVAH simulation yields different conclusions depending on which gridded SWE map is taken as a reference. In the year $2007 / 08$, map203 is available and is considered the best reference. In this case, the snow resources simulated with PREVAH are generally underestimated in the Alpine Rhine region (MAE: $30 \mathrm{~mm}$ ), and partly over- and underestimated in the Valais region (MAE: $16 \mathrm{~mm}$ ). In the region of the rivers Thur, Töss and Glatt, SWE is underestimated in this example (MAE: $48 \mathrm{~mm}$ ). These errors are in the range of the natural variability. If we take map110 as the reference, PREVAH only estimates SWE accurately for a few weeks at the end of winter season in the the Alpine Rhine region (MAE: $24 \mathrm{~mm}$ ) and overestimates SWE in the Valais region (MAE: $24 \mathrm{~mm}$ ). In both cases, the wrong conclusions are drawn when map110 serves as the reference. As the calibration of map110 changes the SWE values towards those of map203 estimates, the model verification would be more realistic if map.cal instead of map110 were taken as reference. For the year 1990/1991, for which map203 is not available, map.cal is a very valuable database for verification, especially at the end of winter season, where the snow resources are underestimated by map 110 . To calibrate and verify hydrological 

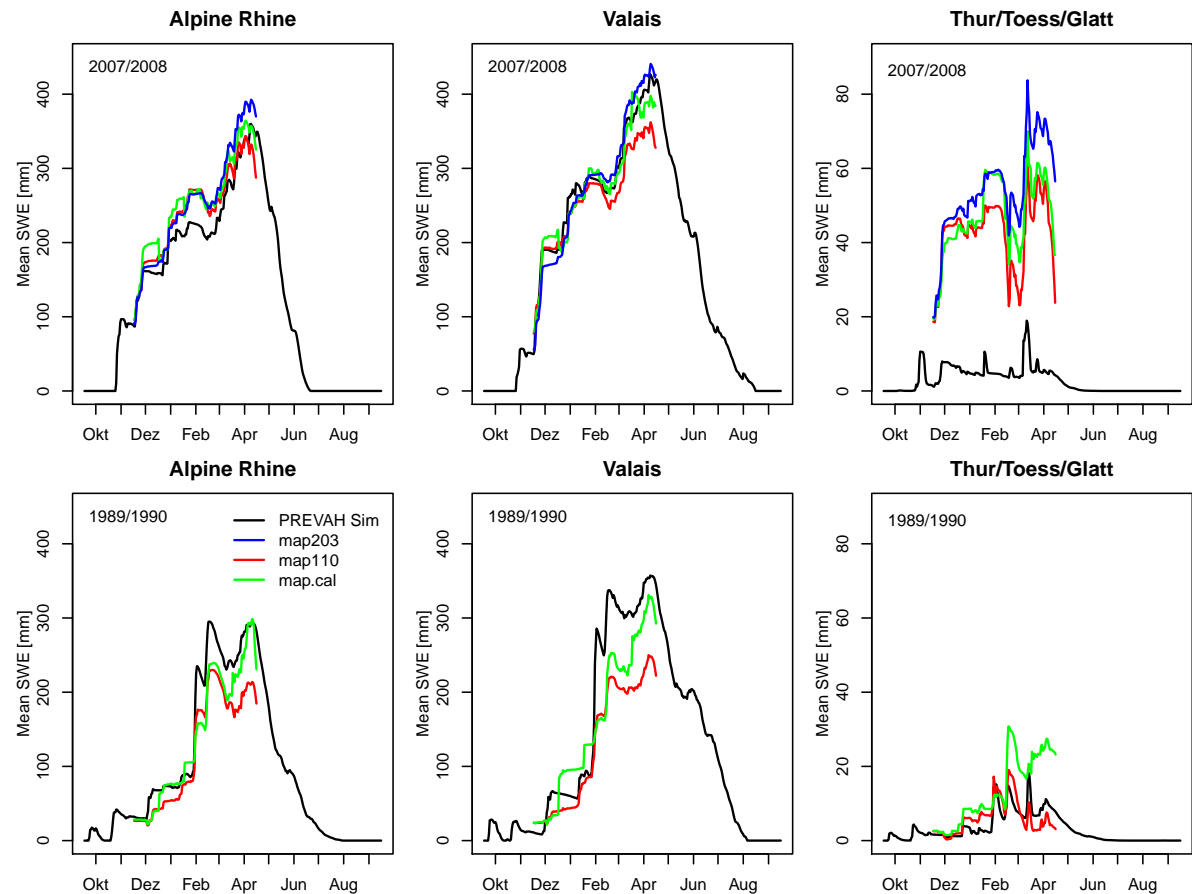

Fig. 12. Daily mean SWE in the Alpine Rhine catchment (left) and the Valais (right) for the hydrological years 2008 (top) and 1991 (bottom). SWE is illustrated as PREVAH simulations (black), map203 (blue), map110 (red) and map110 cal (green).
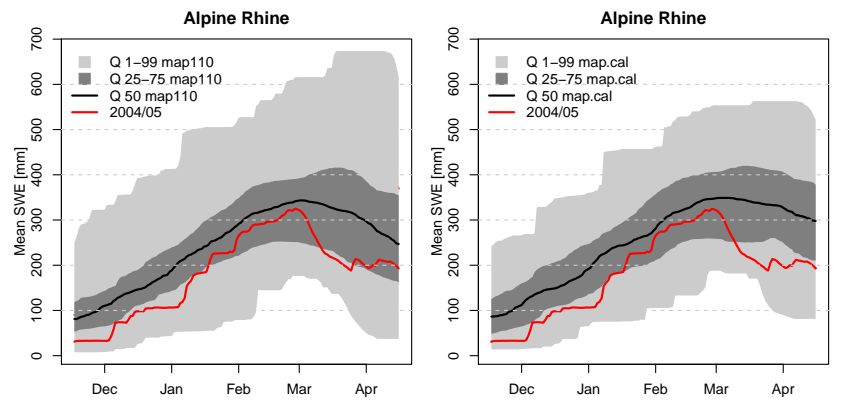

Fig. 13. SWE range (Q1-99) and interquartile range (Q25-75) for the period 1971-2009 in the Alpine Rhine catchment from map110 (left) and map.cal (right). The climatologies are calculated for daily mean SWE with a window of \pm 10 days around the day of interest. The red line is SWE for the year 2004/2005, based on map203.

models against SWE for periods covering the calibration period and the period before, map.cal should be used as the reference to ensure a consistent data set in the best available quality.

\subsection{Estimation of snow resources anomalies}

For research on the water resources in Switzerland or on lake and reservoir management, calculating spatially explicit SWE anomalies is becoming increasingly important, as is comparing current with past situations. Knowledge of the snow water resources and their anomaly as compared to long- term climatology may help operators of hydropower dams in seasonal planning of production and in the coordination of production from different reservoirs located in different regions. Here calibrated long-term SWE climatology is helpful. According to the underlying climatology (map110 or map.cal), various conclusions about the anomalies of a certain winter can be drawn (Fig. 13). The aim is not to decide on how good the two climatologies are. The seasonal pattern and snow amount of the two climatologies agree quite well until March. At the end of the season, the median is lower and the variability is larger in the climatology based on map 110. Both climatologies yield negative SWE anomalies for the winter 2004/2005 (red line in Fig. 13). However, at the end of the winter season in April, if the map110 climatology is used, the anomaly is still in the interquartile range, whereas in the climatology of map.cal the negative anomaly is larger.

\subsection{Predictability of runoff in Neuhausen with SWE in the Alpine Rhine catchment}

The aim of the third application is to illustrate the value of distributed SWE for estimating low-flow events in the following summer using the example of the runoff observed in Neuhausen (yellow triangle in Fig. 1). The minimum daily runoff of each year (1971-2009) was determined for the months of May, June and July. The snow volume used to determine the range of the minimum runoff is the calibrated SWE on 15 April of each year averaged over the catchment of the Alpine Rhine. The scatter plot of 15 April SWE and 
the minimum runoff in May (left), June (middle) and July (right) are shown in Fig. 14. A linear regression is carried out for the log-transformed variables, SWE and runoff. This linear regression is transformed to the non-logarithmic space (black curve). The $95 \%$ predictive interval (dotted lines) is calculated to specify the range where minimal runoff can be expected (Weisberg, 2005). The predictive interval is larger than the confidence interval because, in addition to the estimated uncertainty, the uncertainty of the predictor is also taken into account.

Generally, the minimum runoff is positively related to 15 April SWE. In May the regression curve is rather flat, whereas the relation is more pronounced in July, and even more in June. The variability increases from May to July due to the smaller base values of the snowmelt. For practitioners, the lower curve of the prediction interval should be of interest. This line predicts the worst-case scenarios of minimum discharge for the following May, June and July given the 15 April SWE. The minimum expected runoff is about $40 \%$ lower if 15 April SWE is $200 \mathrm{~mm}$ than if 15 April SWE is $500 \mathrm{~mm}$ (Fig. 14). As illustrated here with 15 April SWE in the Alpine Rhine region, this strategy can be used to create look-up tables for different dates in the winter season and select simple early indicators for low flow in Alpine rivers. These indicators only contain SWE, and thus display the minimum that must be expected for cold conditions with little precipitation.

\section{Conclusions}

The research described here aimed to find a methodology to provide a consistent and homogenised climatology of gridded SWE for Switzerland. A shorter climatology (20012009), consisting of 203 stations (map203), and a longer climatology (1971-2009), based on 110 stations (map110), were used to produce a homogenised SWE data set for Switzerland, namely map.cal, which was calibrated with the quantile mapping method. As far as we are aware, this is the first refinement of a $39 \mathrm{yr}$ long gridded SWE data set. The calibration was implemented for Switzerland during the period 1971-2009 with a resolution of $1 \mathrm{~km} \times 1 \mathrm{~km}$. The analysis of the calibrated SWE maps focused on three regions: the Alpine Rhine, the region including the rivers Thur, Töss and Glatt, and finally the Valais.

The procedure used to generate map110 and map203 is potentially less accurate than locally applied physical models, but it is much easier to use in large basins and global applications, and for studies of very different regions (Sturm et al., 2010). The calibration methodology is independent of region, elevation range and horizontal resolution as it is performed individually for each grid cell. Problems can be expected in two domains: (1) in grid cells that are snow-free on most days in map203, the non-exceedance probability of the lowest snow depths is already very high. Thus the snow depths of these non-exceedance probabilities in map110 are likely to be changed to "no snow". The absolute error is, however, small. (2) Grid cells at altitudes above the highest measurement stations (in our case $>2700 \mathrm{~m}$ a.s.l.) should not be taken at face value in any of the three SWE climatologies.

Comparing map203 with the 203 available station measurements resulted in a RMSE of $50 \mathrm{~mm}$. As the station measurements do not represent the spatial variability, the RMSE is therefore not considered as the true "error". Map203 is, to our knowledge, the best available database for the time period considered. We have demonstrated that quantile mapping can successfully adjust map110 to map203 averaged over a region and a period. Nevertheless, some of the outcomes suggest that, for single years and grid cells, the method and its underlying assumptions might not be free of errors. Therefore using or evaluating single grid cells is not recommended. The evaluation with independent stations and stations outside the calibration period showed that the calibration still could reduce the uncertainty spatially and temporally compared to map110. It is therefore very useful for obtaining information on the water storage in a snowpack on a catchment scale and for investigating SWE anomalies during the recent past.

A closer look at Table 3 shows that the calibration could reduce the RMSE in all regions. For the three study regions, we can conclude that in the region of the rivers Thur, Töss and Glatt, the RMSE could be reduced from 14 to $9 \mathrm{~mm}$. The differences between map203 and map110 are mainly due to changes in the global height trend calculation, as no additional stations have been established in the catchment since 1971. Map110 calculates the global height trend for all of Switzerland, whereas in map203 it is computed separately for seven predefined snow regions. In Valais, the discrepancy between map203 and map110 is larger than in the other two study areas. We assume that this is due to it having a large area above $2000 \mathrm{~m}$ a.s.1. In map1 10 the non-linear trend of SWE over elevation is flat above $2000 \mathrm{~m}$ a.s.l., while this elevation trend is drawn further up to $2700 \mathrm{~m}$ a.s.1. in map203. Here the RMSE is diminished from 78 to $61 \mathrm{~mm}$. The detailed analysis of the Alpine Rhine indicate that the largest deviations of the two climatologies are at the end of winter and at higher elevations, when the RMSE is reduced from 54 to $48 \mathrm{~mm}$.

From these findings, we can conclude that the general underestimation of map110 compared to map203 could be removed over the entire snow period. We have seen that the benefit of including additional stations is smaller at the beginning of the snow season in December due to a small height gradient in SWE, which increases toward April, at the end of the snow season. The calibration has therefore little potential at the beginning of snow season to refine SWE values and more potential at the end of the winter season. Because of the large variability of SWE in Switzerland, the calibrated SWE climatology presented, provides probably the best overview of Swiss snow resources for the recent past. 

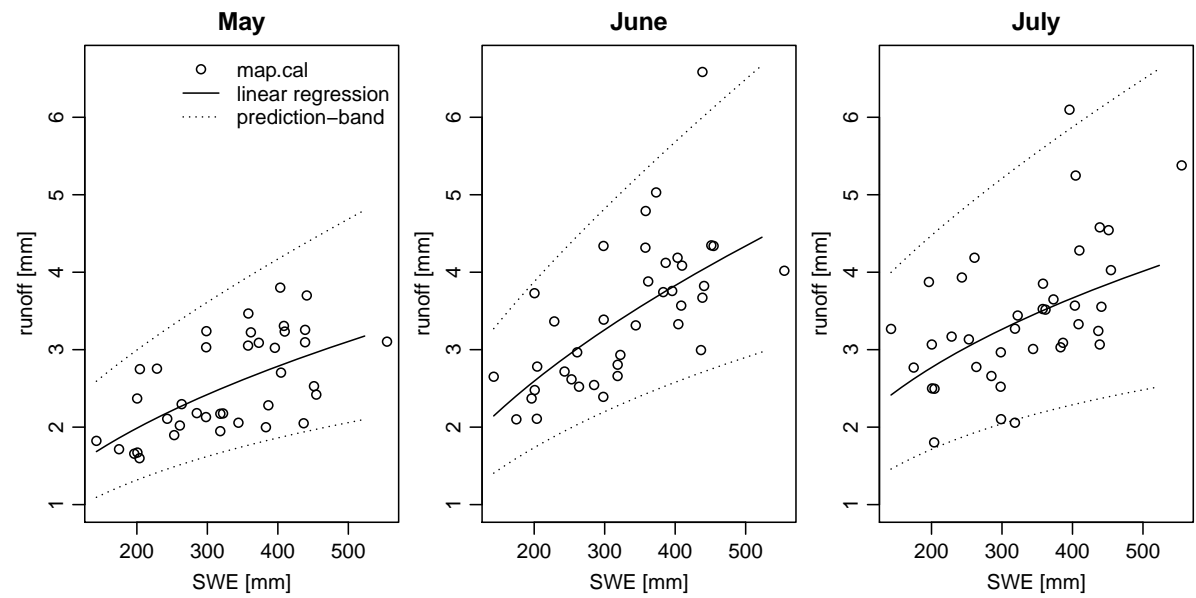

Fig. 14. The minimum runoff of the Rhine River gauge in Neuhausen in May (left), June (middle) and July (right) explained by the SWE on 15 April. The linear regression is computed based on the log-transformed runoff and SWE variables and is then back-transformed to the non-logarithmic space. SWE (black circles) are based on map.cal. The black line is the linear regression line. The dotted line marks the prediction band.

The mean difference between map203 and map110 could be reduced from $-18 \mathrm{~mm}$ to $7 \times 10^{-3} \mathrm{~mm}$ after quantile mapping. Because map203 and map110 are based on the same measurement and model uncertainty, their difference is based on the lower number of stations that are available to produce map110. This difference could be removed with the calibration method quantile mapping.

The gridded SWE climatologies presented are an important contribution to water resource research and applications. Three possible applications have been discussed. Map.cal provides a consistent basis for verifying and parameterising the snow module of fully distributed or semi-distributed hydrological models within the period 1971-2009. The second application showed the importance of a long SWE climatology, approximating current SWE maps, for estimating SWE anomalies. The third application illustrated the potential for forecasting minimum expected runoff in May, June or July using the SWE on 15 April as the sole predictor. We found that in the region of the Alpine Rhine, snow anomalies correlated with the streamflow anomalies of the following season, as did Cayan et al. (1993).

Research with gridded SWE climatologies will always need an update to take into account the latest developments in snow modelling to ensure that it has the best available data. The SWE maps used in this study exhibit, for example, weaknesses in the correct placement of the snow-no-snow borderline and the effect of sub-grid variability. The methodology developed here to refine SWE information can always be used for any future development of available high-end SWE data. Future work with gridded SWE will involve the extension of the work by Fundel et al. (2013), with probabilistic and spatial evaluation of both SWE and discharge predictions. Furthermore, we aim to investigate soon the added value of assimilating SWE information within a hydrological model for extended range forecasts of stream-flow droughts.

Acknowledgements. This study is supported by the Swiss National Research Program Sustainable Water Management (NRP 61 project DROUGHT-CH). We thank all those who helped collect the snow data and the Federal Office of Meteorology and Climatology MeteoSwiss for providing the snow depth data. River runoff observations were provided by the Federal Office for the Environment (FOEN). The data analysis and visualisation were performed with R. We are grateful for the careful and valuable review by A. Fischer, W. Schöner, J. Schöber and an anonymous reviewer. We also thank C. Marty for his comment in the interactive discussion and S. Dingwall for reviewing the language of this article.

Edited by: T. Zhang

\section{References}

Andreadis, K. M. and Lettenmaier, D. P.: Assimilating remotely sensed snow observations into a macroscale hydrology model, Adv. Water Resour., 29, 872-886, 2005.

Auer, M., Meister, R., Stoffel, A., and Weingartner, R.: Analyse und Darstellung der mittleren monatlichen Schneehöhen in der Schweiz, Wasser-Energie-Luft, 96, 173-178, 2004.

Bardossy, A. and Pegram, G.: Downscaling precipitation using regional climate models and circulation patterns toward hydrology, Water Resour. Res., 47, W04505, doi:10.1029/2010WR009689, 2011.

Barnett, T. P., Adam, J. C., and Lettenmaier, D. P.: Potential impacts of a warming climate on water availability in snow-dominated regions, Nature, 438, 303-309, 2005.

Bastiaanssen, W. G. M., Menenti, M., Feddes, R. A., and Holtslag, A. A. M.: A remote sensing surface energy balance algorithm for land (SEBAL) - 1. Formulation, J. Hydrol., 212, 198-212, 1998. 
Bellinger, J., Achleitner, S., Schöber, J., Schöberl, F., Kirnbauer, R., and Schneider, K.: The impact of different elevation steps on simulation of snow covered area and the resulting runoff variance, Adv. Geosci., 32, 69-76, doi:10.5194/adgeo-32-69-2012, 2012.

Beniston, M.: Impacts of climatic change on water and associated economic activities in the Swiss Alps, J. Hydrol., 412, 291-296, 2012.

Bernhard, L. and Zappa, M.: Schlussbericht CCHydrologie: Natürlicher Wasserhaushalt der Schweiz und ihrer bedeutendsten Grosseinzugsgebiete, Tech. rep., Birmensdorf, 2012.

Bierkens, M. F. P. and van Beek, L. P. H.: Seasonal predictability of European discharge: NAO and hydrological response time, J. Hydrometeorol., 10, 953-968, 2009.

Blöschl, G.: Scaling issues in snow hydrology, Hydrol. Process., 13, 2149-2175, 1999.

Boe, J., Terray, L., Habets, F., and Martin, E.: Statistical and dynamical downscaling of the Seine basin climate for hydrometeorological studies, Int. J. Climatol., 27, 1643-1655, 2007.

Bogner, K., Pappenberger, F., and Cloke, H. L.: Technical Note: The normal quantile transformation and its application in a flood forecasting system, Hydrol. Earth Syst. Sci., 16, 1085-1094, doi:10.5194/hess-16-1085-2012, 2012.

Cayan, D. R., Riddle, L. G., and Aguado, E.: The influence of precipitation and temperature on seasonal streamflow in California, Water Resour. Res., 29, 1127-1140, 1993.

Clark, M. P. and Hay, L. E.: Use of medium-range numerical weather prediction model output to produce forecasts of streamflow, J. Hydrometeorol., 5, 15-32, 2004.

Clark, M. P., Slater, A. G., Barrett, A. P., Hay, L. E., McCabe, G. J., Rajagopalan, B., and Leavesley, G. H.: Assimilation of snow covered area information into hydrologic and land-surface models, Adv. Water Resour., 29, 1209-1221, 2006.

Day, G. N.: Extended streamflow forecasting using NWSRFS, J. Water Res. Pl.-Asce, 111, 157-170, 1985.

Dutra, E., Kotlarski, S., Viterbo, P., Balsamo, G., Miranda, P. M. A., Schär, C., Bissolli, P., and Jonas, T.: Snow cover sensitivity to horizontal resolution, parameterizations, and atmospheric forcing in a land surface model, J. Geophys. Res.-Atmos., 116, D21109, doi:10.1029/2011JD016061, 2011.

Egli, L. and Jonas, T.: Hysteretic dynamics of seasonal snow depth distribution in the Swiss Alps, Geophys. Res. Lett., 36, L02501, doi:10.1029/2008GL035545, 2009.

Foppa, N. and Seiz, G.: Inter-annual variations of snow days over Switzerland from 2000-2010 derived from MODIS satellite data, The Cryosphere, 6, 331-342, doi:10.5194/tc-6-331-2012, 2012.

Foppa, N., Stoffel, A., and Meister, R.: Snow depth mapping in the Alps: Merging of in situ and remotely-sensed data., EARSeL eProceedings, 4, 119-129, 2005.

Foppa, N., Stoffel, A., and Meister, R.: Synergy of in situ and space borne observation for snow depth mapping in the Swiss Alps, Int. J. Appl. Earth Obs., 9, 294-310, 2007.

Fundel, F., Walser, A., Liniger, M. A., Frei, C., and Appenzeller, C.: Calibrated Precipitation Forecasts for a Limited-Area Ensemble Forecast System Using Reforecasts, Mon. Weather Rev., 138, 176-189, 2010.

Fundel, F., Jörg-Hess, S., and Zappa, M.: Monthly hydrometeorological ensemble prediction of streamflow droughts and corre- sponding drought indices, Hydrol. Earth Syst. Sci., 17, 395-407, doi:10.5194/hess-17-395-2013, 2013.

Garen, D. C. and Marks, D.: Spatially distributed energy balance snowmelt modelling in a mountainous river basin: estimation of meteorological inputs and verification of model results, J. Hydrol., 315, 126-153, 2005.

Gurtz, J., Baltensweiler, A., and Lang, H.: Spatially distributed hydrotope-based modelling of evapotranspiration and runoff in mountainous basins, Hydrol. Process., 13, 2751-2768, 1999.

Hamill, T. M. and Whitaker, J. S.: Probabilistic quantitative precipitation forecasts based on reforecast analogs: Theory and application, Mon. Weather Rev., 134, 3209-3229, 2006.

Hock, R., Rees, G., Williams, M. W., and Ramirez, E.: Preface Contribution from glaciers and snow cover to runoff from mountains in different climates - Special issue, Hydrol. Process., 20, 2089-2090, 2006.

Hüsler, F., Jonas, T., Wunderle, S., and Albrecht, S.: Validation of a modified snow cover retrieval algorithm from historical 1-km AVHRR data over the European Alps, Remote Sens. Environ., 121, 497-515, 2012.

Hüsler, F., Jonas, T., Riffler, M., Musial, J. P., and Wunderle, S.: A satellite-based snow cover climatology (1985-2011) for the European Alps derived from AVHRR data, The Cryosphere, 8, 73-90, doi:10.5194/tc-8-73-2014, 2014.

Immerzeel, W. W. and Droogers, P.: Calibration of a distributed hydrological model based on satellite evapotranspiration, J. Hydrol., 349, 411-424, 2008.

Ines, A. V. M. and Hansen, J. W.: Bias correction of daily GCM rainfall for crop simulation studies, Agr. Forest Meteorol., 138, 44-53, 2006.

Jonas, T., Marty, C., and Magnusson, J.: Estimating the snow water equivalent from snow depth measurements in the Swiss Alps, J. Hydrol., 378, 161-167, 2009.

Kite, G. W. and Droogers, P.: Comparing evapotranspiration estimates from satellites, hydrological models and field data, J. Hydrol., 229, 3-18, 2000.

Kobierska, F., Jonas, T., Zappa, M., Bavay, M., Magnusson, J., and Bernasconi, S. M.: Future runoff from a partly glacierized watershed in Central Switzerland: A two-model approach, Adv. Water Resour., 55, 204-214, 2013.

Koster, R. D., Mahanama, S. P. P., Livneh, B., Lettenmaier, D. P., and Reichle, R. H.: Skill in streamflow forecasts derived from large-scale estimates of soil moisture and snow, Nat. Geosci., 3, 613-616, 2010.

Laternser, M. and Schneebeli, M.: Long-term snow climate trends of the Swiss Alps (1931-99), Int. J. Climatol., 23, 733-750, 2003.

Li, H. B., Sheffield, J., and Wood, E. F.: Bias correction of monthly precipitation and temperature fields from Intergovernmental Panel on Climate Change AR4 models using equidistant quantile matching, J. Geophys. Res.-Atmos., 115, D10101, doi:10.1029/2009jd012882, 2010.

Liston, G. E. and Elder, K.: A distributed snow-evolution modeling system (SnowModel), J. Hydrometeorol., 7, 1259-1276, 2006.

Martinec, J. and Rango, A.: Indirect Eevaluation of Snow Reserves in Mountain Basins, vol. 205 of Snow, Hydrology and Forests in High Alpine Areas, 1991.

Mauser, W., Prasch, M., and Strasser, U.: Physically based modelling of climate change impact on snow cover dynamics in 
Alpine regions using a stochastic weather generator, Modsim 2007: International Congress on Modelling and Simulation: Land, Water and Environmental Management: Integrated Systems for Sustainability, 10-13 September 2007, Virginia Beach VA, 2007.

Pagano, T. C., Garen, D. C., Perkins, T. R., and Pasteris, P. A.: Daily Updating of Operational Statistical Seasonal Water Supply Forecasts for the western U.S.1, JAWRA J. Am. Water Resour. As., 45, 767-778, 2009.

Panofsky, H. A. and Brier, G. W.: Some applications of statistics to meteorology, Earth and Mineral Sciences Continuing Education College of Earth and Mineral Sciences The Pennsylvania State University, University Park, Pennsylvania, 1968.

Parajka, J. and Blöschl, G.: The value of MODIS snow cover data in validating and calibrating conceptual hydrologic models, J. Hydrol., 358, 240-258, 2008.

Poulin, A., Brissette, F., Leconte, R., Arsenault, R., and Malo, J. S.: Uncertainty of hydrological modelling in climate change impact studies in a Canadian, snow-dominated river basin, J. Hydrol., 409, 626-636, 2011.

Saloranta, T. M.: Simulating snow maps for Norway: description and statistical evaluation of the seNorge snow model, The Cryosphere, 6, 1323-1337, doi:10.5194/tc-6-1323-2012, 2012.

Schär, C., Vasilina, L., Pertziger, F., and Dirren, S.: Seasonal runoff forecasting using precipitation from meteorological data assimilation systems, J. Hydrometeorol., 5, 959-973, 2004.

Sevruk, B.: Correction of Precipitation Measurements. ETH/IASH/WMO Workshop on the Correction of Precipitation Measurements., vol. 23, ETH Zürich, 1986.

Slater, A. G. and Clark, M. P.: Snow data assimilation via an ensemble Kalman filter, J. Hydrometeorol., 7, 478-493, 2006.

Steger, C., Kotlarski, S., Jonas, T., and Schär, C.: Alpine snow cover in a changing climate: a regional climate model perspective, Clim. Dynam., 41, 735-754, doi:10.1007/s00382-012-1545-3, 2012.

Sturm, M., Taras, B., Liston, G. E., Derksen, C., Jonas, T., and Lea, J.: Estimating snow water equivalent using snow depth data and climate classes, J. Hydrometeorol., 11, 1380-1394, 2010.

Thayyen, R. J. and Gergan, J. T.: Role of glaciers in watershed hydrology: a preliminary study of a "Himalayan catchment", The Cryosphere, 4, 115-128, doi:10.5194/tc-4-115-2010, 2010.

Themeß1, M. J., Gobiet, A., and Leuprecht, A.: Empirical-statistical downscaling and error correction of daily precipitation from regional climate models, Int. J. Climatol., 31, 1530-1544, 2011.

Thrasher, B., Maurer, E. P., McKellar, C., and Duffy, P. B.: Technical Note: Bias correcting climate model simulated daily temperature extremes with quantile mapping, Hydrol. Earth Syst. Sci., 16, 3309-3314, doi:10.5194/hess-16-3309-2012, 2012. van Dijk, A. I. J. M. and Renzullo, L. J.: Water resource monitoring systems and the role of satellite observations, Hydrol. Earth Syst. Sci., 15, 39-55, doi:10.5194/hess-15-39-2011, 2011.

Veijalainen, N., Korhonen, J., Vehvilainen, B., and Koivusalo, H.: Modelling and statistical analysis of catchment water balance and discharge in Finland in 1951-2099 using transient climate scenarios, Journal of Water and Climate Change, 3, 55-78, 2012.

Viviroli, D., Weingartner, R., and Messerli, B.: Assessing the hydrological significance of the world's mountains, Mt. Res. Dev., 23, 32-40, 2003.

Viviroli, D., Gurtz, J., and Zappa, M.: The hydrological modelling system part II: physical model description, Geographica Bernensia P40, Institute of Geography, University of Berne, Bern, 2007.

Viviroli, D., Mittelbach, H., Gurtz, J., and Weingartner, R.: Continuous simulation for flood estimation in ungauged mesoscale catchments of Switzerland - Part II: Parameter regionalisation and flood estimation results, J. Hydrol., 377, 208-225, 2009a.

Viviroli, D., Mittelbach, H., Gurtz, J., and Weingartner, R.: Continuous simulation for flood estimation in ungauged mesoscale catchments of Switzerland - Part II: Parameter regionalisation and flood estimation results, J. Hydrol., 377, 208-225, 2009b.

Warscher, M., Strasser, U., Kraller, G., Marke, T., Franz, H., and Kunstmann, H.: Performance of complex snow cover descriptions in a distributed hydrological model system: A case study for the high Alpine terrain of the Berchtesgaden Alps, Water Resour. Res., 49, 2619-2637, 2013.

Weisberg, S.: Applied linear regression, Wiley-Interscience, Hoboken, N. J., 3rd Edn., 2005.

Wilks, D. S.: Statistical methods in the atmospheric sciences, International geophysics series, Academic Press, Amsterdam, Boston, 2nd Edn., 2006.

Witmer, U., Filliger, P., Kunz, S., and Küng, P.: Erfassung, Bearbeitung und Kartierung von Schneedaten in der Schweiz, vol. 25 , Bern, Geographisches Institut der Universität Bern, 1986.

Wood, A. W., Leung, L. R., Sridhar, V., and Lettenmaier, D. P.: Hydrologic implications of dynamical and statistical approaches to downscaling climate model outputs, Clim. Change, 62, 189-216, 2004.

Zappa, M.: Objective quantitative spatial verification of distributed snow cover simulations - an experiment for the whole of Switzerland, Hydrolog. Sci. J., 53, 179-191, 2008.

Zappa, M., Pos, F., Strasser, U., Warmerdam, P., and Gurtz, J.: Seasonal water balance of an Alpine catchment as evaluated by different methods for spatially distributed snowmelt modelling, Nord. Hydrol., 34, 179-202, 2003.

Zappa, M., Bernhard, L., Fundel, F., and Jörg-Hess, S.: Forecasts and scenarios of snow and water resources in Alpine environments, Forum für Wissen, 19-27, 2012 (in German). 